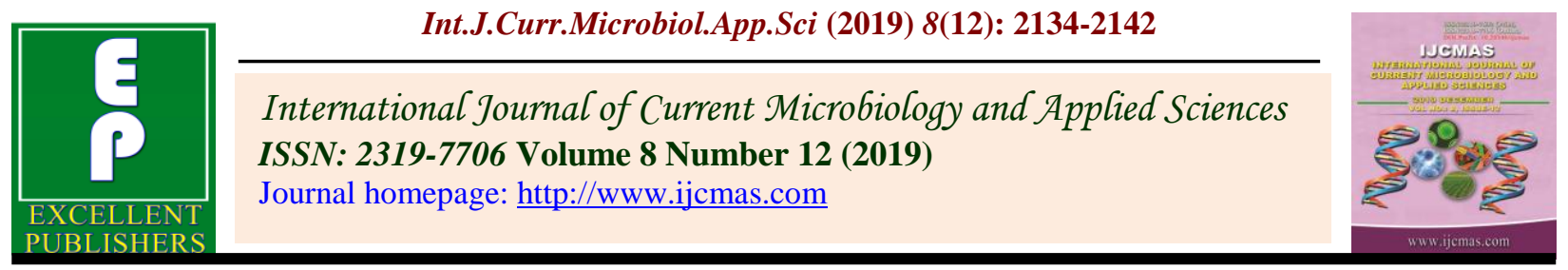

Original Research Article

https://doi.org/10.20546/ijcmas.2019.812.253

\title{
Effect of Various Combinations of Organic and Inorganic Sources on Yield and Quality of Rice in Konkan Region of Maharashtra
}

\author{
P. G. Ahire ${ }^{1 *}$, H. S.Purohit ${ }^{1}$, K. P. Vaidya ${ }^{2}$ and V. D. Kapse ${ }^{2}$
}

${ }^{1}$ Department of Agricultural Chemistry and Soil Science, Rajasthan, College of Agriculture, MPUAT, Udaipur, Rajasthan 313001, India

${ }^{2}$ Dr. Balasaheb Sawant Konkan Krishi Vidyapeeth, Dapoli, Ratnagiri-415712

Maharashtra, India

*Corresponding author

Keywords

Organic, Inorganic, Yield, Quality, Rice

Article Info

Accepted:

17 November 2019

Available Online:

10 December 2019

\section{A B S T R A C T}

A field experiment was conducted during Kharif seasons of 2015-16 and 2016-17 with an objective to assess the effect of different INM treatments on yield and quality of rice (cv. Ratnagiri-1). The treatments comprised of three sources of $\mathrm{N}$ at RDF (urea, FYM and urea + FYM), three levels of $\mathrm{P}$ $(0,75$ and 100 per cent $\mathrm{P}$ of RDF) along with PSB and VAM inoculations (no inoculation and inoculation) and a control making in all nineteen $(18+1)$ treatment combinations. Each treatment was replicated thrice in a randomized block design. Application of 100 per cent $\mathrm{N}$ through an equal integration of urea and FYM when super imposed with 75 per cent $\mathrm{P}$ of RDF along with PSB and VAM inoculations resulted in maximum grain yield and protein content of rice during both the years of investigation. It was closely followed by the treatment $T_{19}$ receiving similar doses of fertilizers/manure as in case of $\mathrm{T}_{18}$ with extra addition of 25 per cent $\mathrm{P}$ of RDF without PSB inoculation. Thus, a saving of 25 per cent $\mathrm{P}$ of RDF for rice crop is possible under INM on Alfisols of Maharashtra.

\section{Introduction}

Rice (Oryza sativa L.) is most common cereal, serving as a stable food for approximately half of the global population. Over 2 billion people in Asia alone derive 80 per cent of their energy needs from rice, which contains 80 per cent carbohydrates, 7-8 per cent protein, 3 per cent fat, and 3 per cent fiber (Anonymous, 2018), which constitutes the principle food for about 60 per cent of the world's population. In India rice cultivation contributes to the total food grain production by 43 per cent and to the total cereal grains production by 46 per 
cent based production system provides the income and employment for more than 50 million households. Rice based production system provides the income and employment for more than 50 million households. More than 90 per cent of the world's rice is produced and consumed in Asia where it is an integral part of culture and tradition. To obtain the better yield farmers have to use more and more fertilizers year after year due to decline in soil fertility. In general, Indian soils have low productivity (FAI, 2001) which may be due to poor fertility of Indian soils, accompanied with adoption of high yielding varieties without adequate fertilization. Inadequate and imbalanced fertilizer use has created imbalance in nutrient supply by the soil leading to soil degradation. There has been a growing emergence of nutrient deficiencies in areas, particularly those, following high intensive cropping. Imbalance fertilizer use has widened NPK nutrient use ratio from 1991-92 onwards. Research data of number of long term trials have also revealed the importance of balance use of nutrients. For achieving high level of production, crop should be supplied with adequate quantities of manures and fertilizers. Now-a-days chemical fertilizers are quite expensive input and their usage over a long period may deplete the soil fertility it is also considered that their indiscriminate usage may also cause environmental pollution problems, soil sickness, reduce the microbial activities and availability of essential nutrients and deteriorate the quality of crops. In developing countries such as India, the most important challenge is to provide sufficient food for the growing population at affordable prices from inelastic land areas. The application of agrochemicals resulted in a many-fold increase in agriculture production but at the cost of soil health. For the present level of production, the estimated nitrogen- phosphorus-potassium removal is about 28 metric tons, resulting in a negative balance of about 10 metric tons. To fulfill such a negative balance of fertilizers, there is an urgent need to identify suitable integrated plant nutrient systems for different crops and cropping systems.

The concept of Integrated Nutrient Management (INM) is aimed to continuous improvement of soil productivity on long term basis through appropriate use of inorganic fertilizers, organic manures, biofertilizers, green manures, crop residues and legume inter-cropping and their scientific management for optimum growth, yield and quality of different crops and cropping systems in specific agro-ecological situations and ensuring environmental safety. Keeping these facts in view, a study entitled "Effect of different organic and inorganic sources on yield and quality of Rice in konkan region of Maharashtra has been undertaken to investigate the efficiency of integrated nutrient management on improving productivity and quality of rice in Konkan region of Maharashtra.

\section{Materials and Methods}

The present investigation was conducted at College of Horticulture, Mulde, Tal. Kudal. Dist. Sindhudurg in the jurisdiction of Dr. Balasaheb Sawant Konkan Krishi Vidyapeeth, Dapoli, Dist. Ratnagiri Maharashtra (India) during Kharif seasons of 2015-16 and 201617.It comprises of nineteen treatments and three replications. Each treatment was replicated thrice in a Randomized Block Design (RBD). The treatment details are given below.

Urea was applied in three splits $(40 \%$ at the time of transplanting, $40 \%$ at the time of tillering and $20 \%$ at the time of panicle initiation) through broadcasting method. SSP as per the treatment plan and $\mathrm{KCl}$ (muriate of potash) applied as a basal dose by deep placement in single dose at the time of 
puddling. FYM was applied through broadcasting in single dose as per the treatment plan before 30 days of transplanting for rice. The rice seedlings before transplanting were carefully washed in running tap water and the roots were dipped in PSB culture slurry (500 g jaggery +5 litres of pre-boiled water $+20 \mathrm{~g}$ PSB culture) and Vesicular Arbuscular Mycorrhiza (VAM) $(250 \mathrm{~g} \mathrm{VAM}+500 \mathrm{~g}$ jaggery $+1000 \mathrm{ml}$ water $\mathrm{kg}^{-1}$ seed) and kept for drying under for three hours and applied as per the treatment plan and then transplanted (Table 1).

The harvested material from each net plot was sundried and threshed. The threshed material (grain) was air dried and weighed plot wise and the yield was computed and expressed in $\mathrm{t}$ $\mathrm{ha}^{-1}$. Straw yield of rice was derived by subtracting grain yield from respective biological yield of individual net plot of each treatment and computed to express it in $\mathrm{t} \mathrm{ha}^{-1}$. Weight of sun dried produce of net plot was recorded and the biological yield was computed in $\mathrm{t} \mathrm{ha}^{-1}$ for individual treatment plot. Harvest index was worked out using following equation.

Harvest Index

Grain yield
= -------------X 100
Biological yield

The protein content will be calculated by multiplying per cent nitrogen content (grain) by 6.25 . The data were statistically analyzed as per the method described by Panse and Sukhatme (1967).

\section{Results and Discussion}

\section{Grain yield of rice $\left(\mathrm{tha}^{-1}\right)$}

A comparison of different treatments indicated that the treatment $T_{18}$ receiving application of
100 per cent $\mathrm{N}$ through an equal integration of urea and FYM with 75 per cent $\mathrm{P}$ of RDF along with PSB and VAM inoculations registered highest yield (5.46 and 5.58t ha $\mathrm{t}^{-1}$ ) during the year 2015-16 and 2016-17, respectively. The lowest grain yield of rice (3.95 and $4.04 \mathrm{t} \mathrm{ha}^{-1}$ ) was observed in the control treatment $\left(\mathrm{T}_{1}\right)$. Application of 100 per cent of $\mathrm{N}$ of RDF through FYM $\left(\mathrm{T}_{5}\right)$ resulted in slight but definite increase in grain yield of rice (4.38 and $4.46 \mathrm{t} \mathrm{ha}^{-1}$ ) and (4.31 and $4.40 \mathrm{t}$ $\mathrm{ha}^{-1}$ ) over the application of 100 per cent $\mathrm{N}$ of RDF through urea $\left(\mathrm{T}_{2}\right)$ during the year 201516 and 2016-17, respectively. But it did not reach to the level of significance. Application of 100 per cent $\mathrm{N}$ of RDF through urea along with 75 per cent $\mathrm{P}$ of RDF through SSP with a blend of PSB inoculation $\left(\mathrm{T}_{3}\right)$ registered slightly higher grain yield of rice (4.92 and $5.02 \mathrm{t} \mathrm{ha}^{-1}$ ) and (4.60 and $4.79 \mathrm{t} \mathrm{ha}^{-1}$ ) over the application of $100 \% \mathrm{~N}$ of RDF through FYM $+75 \% \mathrm{P}$ of RDF along with PSB inoculation $\left(\mathrm{T}_{6}\right)$. However treatment differences were observed to be statistically non-significant. A critical look on the data further indicated that the application of $100 \% \mathrm{~N}$ of RDF through equal integration of urea and FYM $\left(\mathrm{T}_{8}\right)$ produced comparatively higher grain yield of rice (4.56 and $4.68 \mathrm{t} \mathrm{ha}^{-1}$ ) over the treatments receiving $100 \% \mathrm{~N}$ of RDF either through urea $\left(\mathrm{T}_{2}\right)$ or FYM $\left(\mathrm{T}_{5}\right)$ during the year 2015-16 and 2016-17, respectively.

Critical examination of data further revealed that the application of $100 \% \mathrm{~N}$ of RDF through an equal integration of urea and FYM with a blend of $100 \% \mathrm{P}$ of RDF through SSP $\left(\mathrm{T}_{10}\right)$ registered slightly higher yield (4.97 and $\left.5.05 \mathrm{t} \mathrm{ha}^{-1}\right)$ over the treatment $\left(\mathrm{T}_{3}\right)$ receiving application of $100 \% \mathrm{~N}$ of RDF through urea with $75 \% \mathrm{P}$ of RDF along with PSB inoculation (4.92 and $5.02 \mathrm{t} \mathrm{ha}^{-1}$ ). Furthermore treatment receiving application of $100 \% \mathrm{~N}$ of RDF through an equal integration of urea and FYM with $100 \%$ P of RDF through SSP along with VAM inoculation $\left(\mathrm{T}_{19}\right)$ showed a definite 
increase in rice grain yield (5.31 and $5.47 \mathrm{t} \mathrm{ha}^{-}$

${ }^{1}$ ) over respective treatment $\left(\mathrm{T}_{10}\right)$ without PSB and VAM inoculations (4.97 and $5.05 \mathrm{t} \mathrm{ha}^{-1}$ ). Seed inoculation of PSB and VAM with different $\mathrm{N}$ sources viz. urea, FYM and integration of urea and FYM in an equal proportion did not show any significant increase in grain yield of rice. Treatment $T_{18}$ resulted in comparatively higher increase in grain yield of rice by 0.73 and $0.65 \mathrm{t} \mathrm{ha}^{-1}$ over the treatment receiving $\mathrm{T}_{4}$ (RDFas recommended by Dr. BSKKV, Dapoli, Maharashtra) during the year 2015-16 and 2016-17, respectively.

Application of phosphorus at two levels viz. 75 per cent and 100 per cent $P$ of RDF with a blend of 100 per cent $\mathrm{N}$ of RDF through an equal integration of urea and FYM ( $\mathrm{T}_{9}$ and $\mathrm{T}_{10}$ ) also resulted in comparatively higher grain yield of rice over respective treatments receiving 100 per cent $\mathrm{N}$ either through urea $\left(\mathrm{T}_{3}\right.$ and $\left.\mathrm{T}_{4}\right)$ or solely through FYM $\left(\mathrm{T}_{6}\right.$ and $\left.\mathrm{T}_{7}\right)$ during both the years of investigation.

\section{Straw yield of rice $\left(\mathrm{tha}^{-1}\right)$}

Maximum straw yield $(8.18,8.40$ and $8.29 \mathrm{t}$ $\mathrm{ha}^{-1}$ ) of rice was registered in the treatment $\mathrm{T}_{18}$ receiving 50 per cent $\mathrm{N}$ through urea +50 per cent $\mathrm{N}$ through FYM when super imposed with 75 per cent $\mathrm{P}$ of RDF and PSB+ VAM inoculations, which was closely followed by the treatment $\mathrm{T}_{19}\left(7.99,8.19\right.$ and $\left.8.09 \mathrm{t} \mathrm{ha}^{-1}\right)$ receiving same doses of fertilizers as in $T_{18}$ with extra addition of 25 per cent $\mathrm{P}$ of $\mathrm{RDF}$ and without PSB inoculation during both the years (2015-16 and 2016-17) of investigations as well as in pooled analysis, respectively.

\section{Biological yield of rice ( $\left.\mathrm{ha}^{-1}\right)$}

The biological yield of rice followed the similar pattern to that of grain and straw yield of rice. The maximum biological yield of rice was recorded in the treatment $\mathrm{T}_{18}$.

\section{Harvest index of rice $(\%)$}

The harvest index of rice which is the ratio of grain and biological yield multiplied by hundred was found to be constant as a result of various treatment combinations and varied between a narrow range of 39.67 to 40.60 , 39.57 to 40.34 and 39.61 to 40.27 per cent during the years 2015-16, 2016-17 and in pooled analysis, respectively. This showed that the harvest index remained unaffected due to various treatments comprising of sole application of urea, FYM and urea with FYM when super imposed with $\mathrm{P}$ and PSB and VAM inoculations (Table 2).

\section{Quality parameter [Protein content (\%)] of rice grain}

Data when studied revealed that the protein content in rice grain ranged from 5.38 to 8.00 per cent, 5.67 to 8.26 per cent and 5.52 to 8.13 with average values of $6.94,7.14$ and 7.04 per cent during the years 2015-16, 2016-17 and in pooled analysis, respectively. Data further, indicated that the lowest values of protein (5.38, 5.67 and $5.52 \%$ ) content were seen in the control treatment $\left(\mathrm{T}_{1}\right)$ while the highest values of protein $(8.00,8.26$ and $8.13 \%$ ) content were observed in the treatment $\left(\mathrm{T}_{18}\right)$ receiving $100 \% \mathrm{~N}$ of $\mathrm{RDF}$ through equal integration of urea and FYM when super imposed with 75 per cent $\mathrm{P}$ of RDF along with $\mathrm{PSB}+\mathrm{VAM}$ inoculations.

\section{Yield of rice}

In general considerable improvement in the grain of rice was observed due to the application of 100 per cent $\mathrm{N}$ of RDF either through $\mathrm{N}$ alone or in combination with 75 and 100 per cent $\mathrm{P}$ of RDF with or without PSB inoculation. Increase in the grain yield of rice in the present investigation was expected because applications of fertilizers are based on recommendations. 
Table.1 Details of the treatments

\begin{tabular}{|c|c|}
\hline Notations & Treatment \\
\hline $\mathbf{T}_{1}$ & Control \\
\hline $\mathbf{T}_{2}$ & $100 \% \mathrm{~N}$ of RDF through Urea \\
\hline $\mathbf{T}_{3}$ & $\mathrm{~T}_{2}+75 \% \mathrm{P}$ of RDF through SSP+PSB \\
\hline $\mathbf{T}_{4}$ & $T_{2}+100 \% P$ of RDF through SSP \\
\hline $\mathbf{T}_{\mathbf{5}}$ & $100 \% \mathrm{~N}$ of RDF through FYM \\
\hline$T_{6}$ & $\mathrm{~T}_{5}+75 \% \mathrm{P}$ of RDF through SSP+PSB \\
\hline $\mathbf{T}_{7}$ & $T_{5}+100 \%$ P of RDF through SSP \\
\hline $\mathbf{T}_{8}$ & $50 \% \mathrm{~N}$ of RDF through Urea $+50 \% \mathrm{~N}$ of RDF through FYM \\
\hline $\mathbf{T}_{9}$ & $\mathrm{~T}_{8}+75 \% \mathrm{P}$ of RDF through SSP+PSB \\
\hline $\mathbf{T}_{10}$ & $T_{8}+100 \%$ P of RDF through SSP \\
\hline $\mathbf{T}_{11}$ & $\mathbf{T}_{2}+\mathbf{V A M}$ \\
\hline $\mathbf{T}_{12}$ & $\mathbf{T}_{3}+\mathbf{V A M}$ \\
\hline $\mathbf{T}_{13}$ & $\mathbf{T}_{4}+\mathbf{V A M}$ \\
\hline $\mathbf{T}_{14}$ & $\mathbf{T}_{5}+\mathbf{V A M}$ \\
\hline $\mathbf{T}_{15}$ & $\mathbf{T}_{6}+\mathrm{VAM}$ \\
\hline $\mathbf{T}_{16}$ & $\mathbf{T}_{7}+\mathbf{V A M}$ \\
\hline $\mathbf{T}_{17}$ & $\mathbf{T}_{8}+\mathrm{VAM}$ \\
\hline $\mathbf{T}_{18}$ & $\mathbf{T}_{9}+\mathrm{VAM}$ \\
\hline$T_{19}$ & $T_{10}+$ VAM \\
\hline
\end{tabular}


Table.2 Effect of different organic and inorganic sources on grain, straw, biological yields (t/ha) and harvest index (\%) of rice crop

\begin{tabular}{|c|c|c|c|c|c|c|c|c|c|c|c|c|c|}
\hline & \multirow[t]{2}{*}{ Treatments } & \multicolumn{4}{|c|}{ 2015-16 } & \multicolumn{4}{|c|}{ 2016-17 } & \multicolumn{4}{|c|}{ Pooled } \\
\hline & & $\begin{array}{c}\text { Grain } \\
\text { yield } \\
\text { (t/ha) }\end{array}$ & $\begin{array}{c}\text { Stover } \\
\text { yield } \\
\text { (t/ha) }\end{array}$ & $\begin{array}{c}\text { Biological } \\
\text { yield } \\
\text { (t/ha) }\end{array}$ & $\begin{array}{c}\text { Harvest } \\
\text { index } \\
(\%)\end{array}$ & $\begin{array}{c}\text { Grain } \\
\text { yield } \\
\text { (t/ha) }\end{array}$ & $\begin{array}{c}\text { Stover } \\
\text { yield } \\
\text { (t/ha) }\end{array}$ & $\begin{array}{c}\text { Biological } \\
\text { yield } \\
\text { (t/ha) }\end{array}$ & $\begin{array}{c}\text { Harvest } \\
\text { index } \\
(\%)\end{array}$ & $\begin{array}{c}\text { Grain } \\
\text { yield } \\
\text { (t/ha) }\end{array}$ & $\begin{array}{c}\text { Stover } \\
\text { yield } \\
\text { (t/ha) }\end{array}$ & $\begin{array}{c}\text { Biological } \\
\text { yield } \\
\text { (t/ha) }\end{array}$ & $\begin{array}{c}\text { Harvest } \\
\text { index } \\
(\%)\end{array}$ \\
\hline $\mathbf{T}_{1}$ & Control & 3.95 & 5.91 & 9.86 & 40.06 & 4.04 & 6.06 & 10.10 & 40.00 & 3.99 & 5.99 & 9.97 & 40.03 \\
\hline $\mathbf{T}_{2}$ & $100 \% \mathrm{~N}$ of RDF through Urea & 4.31 & 6.47 & 10.78 & 39.98 & 4.40 & 6.58 & 10.97 & 40.11 & 4.35 & 6.52 & 10.86 & 40.05 \\
\hline $\mathbf{T}_{\mathbf{3}}$ & $\begin{array}{c}\mathrm{T}_{2}+75 \% \mathrm{P} \text { of RDF through } \\
\text { SSP+PSB }\end{array}$ & 4.92 & 7.34 & 12.26 & 40.13 & 5.02 & 7.55 & 12.57 & 39.94 & 4.97 & 7.45 & 12.41 & 40.02 \\
\hline $\mathbf{T}_{4}$ & $\begin{array}{c}\mathrm{T}_{2}+100 \% \mathrm{P} \text { of RDF through } \\
\text { SSP }\end{array}$ & 4.73 & 7.10 & 11.83 & 39.98 & 4.93 & 7.43 & 12.36 & 39.89 & 4.83 & 7.26 & 12.10 & 39.92 \\
\hline $\mathbf{T}_{5}$ & $100 \% \mathrm{~N}$ of RDF through FYM & 4.38 & 6.66 & 11.04 & 39.67 & 4.46 & 6.81 & 11.27 & 39.57 & 4.42 & 6.74 & 11.15 & 39.61 \\
\hline$T_{6}$ & $\begin{array}{c}\mathrm{T}_{5}+75 \% \mathrm{P} \text { of RDF through } \\
\mathrm{SSP}+\mathrm{PSB}\end{array}$ & 4.60 & 6.89 & 11.49 & 40.03 & 4.79 & 7.18 & 11.97 & 39.98 & 4.69 & 7.03 & 11.72 & 40.01 \\
\hline $\mathbf{T}_{7}$ & $\begin{array}{c}\mathrm{T}_{5}+100 \% \mathrm{P} \text { of RDF through } \\
\mathrm{SSP}\end{array}$ & 4.12 & 6.20 & 10.32 & 39.92 & 4.18 & 6.26 & 10.45 & 40.00 & 4.15 & 6.23 & 10.36 & 39.96 \\
\hline $\mathbf{T}_{8}$ & $\begin{array}{c}50 \% \mathrm{~N} \text { of RDF through Urea }+50 \\
\% \mathrm{~N} \text { of RDF through FYM }\end{array}$ & 4.56 & 6.84 & 11.39 & 40.04 & 4.68 & 6.92 & 11.60 & 40.34 & 4.62 & 6.88 & 11.49 & 40.20 \\
\hline $\mathbf{T}_{9}$ & $\begin{array}{c}\mathrm{T}_{8}+75 \% \mathrm{P} \text { of RDF through } \\
\text { SSP+PSB }\end{array}$ & 5.01 & 7.33 & 12.34 & 40.60 & 5.14 & 7.72 & 12.86 & 39.97 & 5.07 & 7.52 & 12.59 & 40.27 \\
\hline $\mathbf{T}_{10}$ & $\mathrm{~T}_{8}+100 \% \mathrm{P}$ of RDF through SSP & 4.97 & 7.44 & 12.40 & 40.08 & 5.05 & 7.58 & 12.63 & 39.98 & 5.01 & 7.51 & 12.51 & 40.04 \\
\hline $\mathbf{T}_{11}$ & $\mathrm{~T}_{2}+\mathrm{VAM}$ & 5.03 & 7.54 & 12.57 & 40.02 & 5.16 & 7.76 & 12.92 & 39.94 & 5.10 & 7.65 & 12.76 & 39.97 \\
\hline $\mathbf{T}_{12}$ & $\mathrm{~T}_{3}+\mathrm{VAM}$ & 5.23 & 7.86 & 13.10 & 39.92 & 5.38 & 8.06 & 13.44 & 40.03 & 5.30 & 7.96 & 13.26 & 39.97 \\
\hline $\mathbf{T}_{13}$ & $\mathrm{~T}_{4}+\mathrm{VAM}$ & 5.21 & 7.81 & 13.02 & 40.02 & 5.36 & 8.04 & 13.40 & 40.00 & 5.29 & 7.92 & 13.22 & 40.01 \\
\hline $\mathbf{T}_{14}$ & $\mathrm{~T}_{5}+\mathrm{VAM}$ & 5.08 & 7.60 & 12.68 & 40.06 & 5.19 & 7.79 & 12.98 & 39.98 & 5.14 & 7.70 & 12.84 & 40.03 \\
\hline $\mathbf{T}_{15}$ & $\mathrm{~T}_{6}+\mathrm{VAM}$ & 5.19 & 7.82 & 13.01 & 39.89 & 5.30 & 7.98 & 13.28 & 39.91 & 5.24 & 7.90 & 13.13 & 39.90 \\
\hline $\mathbf{T}_{16}$ & $\mathrm{~T}_{7}+\mathrm{VAM}$ & 5.16 & 7.77 & 12.93 & 39.91 & 5.26 & 7.90 & 13.16 & 39.97 & 5.21 & 7.84 & 13.04 & 39.95 \\
\hline $\mathbf{T}_{17}$ & $\mathrm{~T}_{8}+\mathrm{VAM}$ & 5.13 & 7.69 & 12.82 & 40.02 & 5.23 & 7.93 & 13.16 & 39.74 & 5.18 & 7.81 & 12.99 & 39.87 \\
\hline $\mathbf{T}_{18}$ & $\mathrm{~T}_{9}+\mathrm{VAM}$ & 5.46 & 8.18 & 13.64 & 40.03 & 5.58 & 8.40 & 13.99 & 39.89 & 5.52 & 8.29 & 13.81 & 39.97 \\
\hline $\mathbf{T}_{19}$ & $\mathrm{~T}_{10}+\mathrm{VAM}$ & 5.31 & 7.99 & 13.30 & 39.92 & 5.47 & 8.19 & 13.67 & 40.01 & 5.39 & 8.09 & 13.48 & 39.98 \\
\hline & Mean & 4.86 & 7.29 & 12.15 & 40.02 & 4.98 & 7.48 & 12.46 & 39.96 & 4.92 & 7.38 & 12.30 & 39.99 \\
\hline & SEm \pm & 0.31 & 0.46 & 0.52 & 1.44 & 0.10 & 0.30 & 0.34 & 1.37 & 0.018 & 0.041 & 0.054 & 0.097 \\
\hline & CD $(0.05 \%)$ & 0.89 & 1.32 & 1.49 & NS & 0.30 & 0.86 & 0.97 & NS & 0.05 & 0.12 & 0.16 & NS \\
\hline
\end{tabular}


Table.3 Effect of different organic and inorganic sources on quality parameter [Protein content $(\%)$ ] of Rice grain

\begin{tabular}{|c|c|c|c|c|}
\hline $\begin{array}{l}\text { Tr. } \\
\text { No. }\end{array}$ & Treatments & 2015 & 2016 & Pooled \\
\hline $\mathbf{T}_{1}$ & Control & 5.38 & 5.67 & 5.52 \\
\hline $\mathbf{T}_{2}$ & $100 \% \mathrm{~N}$ of RDF through Urea & 5.87 & 6.00 & 5.94 \\
\hline $\mathbf{T}_{3}$ & $\mathrm{~T}_{2}+75 \% \mathrm{P}$ of RDF through SSP+PSB & 7.08 & 7.23 & 7.16 \\
\hline $\mathbf{T}_{4}$ & $\mathrm{~T}_{2}+100 \% \mathrm{P}$ of RDF through SSP & 6.23 & 6.43 & 6.33 \\
\hline $\mathbf{T}_{5}$ & $100 \% \mathrm{~N}$ of RDF through FYM & 6.72 & 6.85 & 6.78 \\
\hline $\mathbf{T}_{6}$ & $\mathrm{~T}_{5}+75 \% \mathrm{P}$ of RDF through SSP+PSB & 7.27 & 7.48 & 7.38 \\
\hline $\mathbf{T}_{7}$ & $\mathrm{~T}_{5}+100 \% \mathrm{P}$ of RDF through SSP & 6.97 & 7.07 & 7.02 \\
\hline $\mathbf{T}_{8}$ & $\begin{array}{c}50 \% \mathrm{~N} \text { of RDF through Urea }+50 \% \mathrm{~N} \text { of RDF through } \\
\text { FYM }\end{array}$ & 6.00 & 6.32 & 6.16 \\
\hline $\mathbf{T}_{9}$ & $\mathrm{~T}_{8}+75 \% \mathrm{P}$ of RDF through SSP+PSB & 7.22 & 7.51 & 7.37 \\
\hline $\mathbf{T}_{10}$ & $\mathrm{~T}_{8}+100 \% \mathrm{P}$ of RDF through SSP & 6.76 & 7.03 & 6.90 \\
\hline$T_{11}$ & $\mathrm{~T}_{2}+\mathrm{VAM}$ & 6.40 & 6.62 & 6.51 \\
\hline $\mathbf{T}_{12}$ & $\mathrm{~T}_{3}+\mathrm{VAM}$ & 7.46 & 7.68 & 7.57 \\
\hline $\mathbf{T}_{13}$ & $\mathrm{~T}_{4}+\mathrm{VAM}$ & 7.10 & 7.30 & 7.20 \\
\hline $\mathbf{T}_{14}$ & $\mathrm{~T}_{5}+\mathrm{VAM}$ & 7.29 & 7.47 & 7.38 \\
\hline $\mathbf{T}_{15}$ & $\mathrm{~T}_{6}+\mathrm{VAM}$ & 7.80 & 7.97 & 7.88 \\
\hline $\mathbf{T}_{16}$ & $\mathrm{~T}_{7}+\mathrm{VAM}$ & 7.43 & 7.66 & 7.55 \\
\hline $\mathbf{T}_{17}$ & $\mathrm{~T}_{8}+\mathrm{VAM}$ & 6.86 & 7.04 & 6.95 \\
\hline $\mathbf{T}_{18}$ & $\mathrm{~T}_{9}+\mathrm{VAM}$ & 8.00 & 8.26 & 8.13 \\
\hline \multirow[t]{4}{*}{$T_{19}$} & $\mathrm{~T}_{10}+\mathrm{VAM}$ & 7.93 & 8.12 & 8.03 \\
\hline & Mean & 6.94 & 7.14 & 7.04 \\
\hline & $\mathrm{SEm} \pm$ & 0.21 & 0.20 & 0.03 \\
\hline & $\mathrm{CD}(0.05 \%)$ & 0.61 & 0.57 & 0.09 \\
\hline
\end{tabular}

A significant increase in grain yield of rice (5.46 and $5.58 \mathrm{t} \mathrm{ha}^{-1}$ ) over control was recorded in the treatment $\mathrm{T}_{18}$ receiving application of $\mathrm{N}$ through integration of urea with FYM with super imposition of 75 per cent $\mathrm{P}$ of RDF along with PSB and VAM inoculations during the years 2015-16 and 2016-17, respectively. Such an improvement in yield of crop under study is attributed to increased supply of nutrients making a 
congenial environment for growth in the rhizosphere. The right kind of nutrients required by the crops may not be achieved from a single source. The comparison of 100 per cent $\mathrm{N}$ of RDF through different sources with a superimposition of 75 per cent $P$ of RDF along with PSB and VAM inoculations clearly showed added benefits of $\mathrm{N}$ through integration of urea with FYM and super imposition of 75 per cent $\mathrm{P}$ of RDF with $\left(\mathrm{T}_{18}\right)$ PSB and VAM inoculations or 100 per cent $P$ of RDF without $\left(\mathrm{T}_{17}\right)$ PSB and VAM inoculations over treatments receiving $\mathrm{N}$ through urea alone or solely through FYM even when super imposed with 75 per cent and 100 per cent $\mathrm{P}$ of RDF along with $\left(\mathrm{T}_{12}\right.$ and $\mathrm{T}_{15}$ ) or without $\left(\mathrm{T}_{4}\right.$ and $\left.\mathrm{T}_{7}\right)$ PSB and VAM inoculations, respectively. PSB and VAM inoculations caused an increase in the grain yield of rice during both the years. The results of present investigation are in conformity with the results reported by several researchers (Vaidya, 2005; Gaidhani, 2008, Rane, 2018) (Table 3).

However, PSB and VAM inoculation showed it's significance on grain yield of rice, which may be attributed to its phosphate solubilizing ability. PSB and VAM solubilize the fixed native $\mathrm{P}$ in soil by production of organic acids in micro environment around the root. Organic acids solubilize more $\mathrm{P}$ than inorganic acids at same $\mathrm{pH}$ due to chelating effect of the former. Further, production of $\mathrm{CO}_{2}$ by soil microorganisms and plant roots leads to formation of carbonic acid which also encourages solubilization of insoluble $\mathrm{P}$ (Somani, 2002). These results are in close conformity with the findings reported by several researchers (Vaidya, 2005; Gaidhani, 2008; Rane, 2018).

\section{Protein content}

Protein content of grain of rice followed the similar trend as observed in the nitrogen content of grains, because protein content was computed by multiplying $\mathrm{N}$ content with the factor of 6.25. Significant and the highest protein content in grain of rice was recorded in the treatment $\left(\mathrm{T}_{18}\right)$. Since protein content is function of nitrogen accumulation, higher nitrogen content resulting in the higher protein content. These results are in close conformity with the results reported by Chavan (2016) and Mali (2018).

\section{References}

Anonymous (2016). Agricultural Statistical Information. Maharashtra State, 2016.

Chavan, A.R. (2016) Effect of crop establishment techniques and nutrient management on upland rice (Oryza sativa L.) during Kharif season. M. Sc. (Agri.). Thesis submitted to Dr. BSKKV. Dapoli, Dist. Ratnagiri(Unpublished).

FAI (2001). Fertility Index of Indian Soil, Fertilizer Statistics, 2000-2001.

Gaidhani, S.M. (2008) Effect of integrated nutrient management on yield, partitioning and uptake by rice and on fertility status of lateritic soils of Konkan. M.Sc. (Agri.) Thesis submitted to Dr. Balasaheb Sawant Konkan Krishi Vidyapeeth, Dapoli, Dist. Ratnagiri, Maharashtra (Unpublished).

Mali, R.G. (2018) Organic nutrient management in kharif rice (Oryza sativa L.). M. Sc. (Agri.). Thesis submitted to Dr. BSKKV. Dapoli, Dist. Ratnagiri, Maharashtra (Unpublished).

Panse, V.G. and Sukhatme, P.V. (1967) Statistical method for Agricultural Workers., I.C.A.R., New Delhi.

Rane, H.D. (2018) Effect of different levels of nitrogen and silica on yield and uptake of nutrients by rice in lateritic soils. M. Sc. (Agri.). Thesis submitted to Dr. 
BSKKV. Dapoli, Dist. Ratnagiri, Maharashtra (Unpublished).

Somani, L.L. (2002). Phosphatic Biofertilizers Agrotech Publishing Academy, Udaipur, $224 \mathrm{p}$.

Vaidya, K.P. (2005) Integrated nutrient management in rice-cowpea cropping sequence on Alfisols of Maharashtra. $\mathrm{Ph}$. D. (Agri) Thesis submitted to Maharana Pratap University of Agriculture and Technology, Udaipur, Rajasthan (Unpublished).

\section{How to cite this article:}

Ahire, P. G., H. S. Purohit, K. P. Vaidya and Kapse, V. D. 2019. Effect of Various Combinations of Organic and Inorganic Sources on Yield and Quality of Rice in Konkan Region of Maharashtra. Int.J.Curr.Microbiol.App.Sci. 8(12): 2134-2142. doi: https://doi.org/10.20546/ijcmas.2019.812.253 